\title{
ANALYSIS OF THE REASONS FOR THE LEAKAGE OF A BOILER WATER-WALL TUBE IN A POWER PLANT
}

\author{
ANALIZA VZROKOV PUŠČANJA STEN CEVI IZMENJEVALNIKOV \\ TOPLOTE V TERMOELEKTRARNI
}

\author{
Ruidong Guo ${ }^{1}$, Song Xue ${ }^{1,2 *}$, Tao Yang ${ }^{1}$, Xuedong Liu ${ }^{1}$ \\ ${ }^{1}$ College of Manufacturing Science and Engineering, Southwest University of Science and Technology, Mianyang 621010, China \\ ${ }^{2}$ Key Laboratory of Testing Technology for Manufacturing Process, Ministry of Education, Mianyang 621010, China
}

Prejem rokopisa - received: 2019-08-27; sprejem za objavo - accepted for publication: 2019-11-08

doi:10.17222/mit.2019.205

\begin{abstract}
In the present research, the leakage causes of a boiler water-wall tube, with an outside diameter of $60 \mathrm{~mm}$ and a thickness of $6.75 \mathrm{~mm}$, that transmits the water medium have been studied. Leakage occurred on the fire-facing side of the tube and close to the boiler. Various techniques including visual inspection, chemical composition analysis, Vickers hardness test, tube wall thickness measurements, mechanical performance testing, optical microscopy and energy-dispersive spectroscopy were carried out to verify the probable cause of failure. Deposits formed on the inner wall of the tube, which caused local heat-transfer performance of the tube to decrease, formed an overheating characteristic in the microstructure, and softened the tube wall and made the tube wall thinner near the leakage points. The softening of the tube wall reduces the measured hardness at the edge of the leakage point. In addition, due to the localized wall thinning and softening, the tube cannot withstand the stress flowing liquids and gases, with the result that the tube was bulging and deforming. Local overheating caused the degeneration of the initial ferrite-pearlite microstructure. In the microstructure near the leakage point of the water-wall tube, carbides were spheroidized and coalesced. According to the investigation, it was concluded that the local heat-transfer performance of the water-wall tube decreased and the tube performance deteriorated due to the deposits formed on the inner surface. The combination of localized overheating and tube wall thinning led to the tube's premature bulging and failure while running.

Keywords: boiler water-wall tube, overheating, deposits, leakage
\end{abstract}

V članku avtorji opisujejo raziskavo vzrokov puščanja sten cevi izmenjevalnikov toplote. Cevi, po katerih se pretaka voda, imajo zunanji premer $60 \mathrm{~mm}$ in debelino sten $6,75 \mathrm{~mm}$. Netesnosti so se zgodile na ogrevani strani cevi in v bližini izmenjevalnika. Za analizo odpovedi so avtorji uporabili različne tehnike, kot so: vizualni pregled, analiza kemijske sestave, meritve trdote po Vickersu, meritve debeline sten cevi, določitev mehanskih lastnosti (natezni oz. trgalni preizkus), optična mikroskopija in energijska disperzijska spektroskopija. Usedline, nastale na notranjih stenah cevi, so povzročile spremembo prenosa toplote in prišlo je do pregrevanja sten cevi ter sprememb v mikrostrukturi. Prišlo je do mehčanja materiala in v okolici mest, kjer je prišlo do puščanja, so bile stene cevi stanjšane. Mehčanje sten cevi je znižalo izmerjeno trdoto materiala na robovih lukenj in razpok (netesnosti). Dodatno, zaradi lokalnega tanjšanja debeline sten cevi in mehčanja, cevi niso zmogle prenašati obremenitve (napetosti) pretakajoče se kapljevine in plinov, zaradi česar so se cevi napihovale (nabrekale) in deformirale. Lokalno pregrevanje sten cevi je povzročilo spremembo feritno-perlitne mikrostrukture. V bližini lukenj in razpok na poškodovanih stenah cevi, kjer so cevi puščale, je prišlo v mikrostrukturi do sferoidizacije (okrogljenja) in združevanja in rasti karbidov. Na osnovi raziskave avtorji v zaključku ugotavljajo, da se je zaradi usedlin na notranjih stenah cevi lokalno zmanjšal prenos toplote. Kombinacija lokalnega pregrevanja in tanjšanja sten cevi je privedla do njihove prehitre deformacije in odpovedi.

Ključne besede: stene cevi izmenjevalnikov toplote, pregrevanje, usedline, netesnost

\section{INTRODUCTION}

Economic and social development is greatly affected by power supply and distribution. ${ }^{1,2}$ Thermal power plants use combustibles (such as coal) as the fuel to produce electricity. The continued normal operation of the equipment and components of the power plant is a prerequisite for ensuring uninterrupted power supply. ${ }^{3}$ In a thermal power station, proper functioning of the boiler water-wall tube, heat exchanger, steam turbine, generators, etc., is critical to maintaining an uninterrupted electricity supply. As long as a single device of the power-generation system fails, the whole power supply will be affected. Boiler water wall tube failure is a major

*Corresponding author's e-mail: xuesong2004@126.com (Song Xue) cause of power plant shutdown, and similar incidents have been reported in many power plants. ${ }^{4-6}$

Modern thermal power plants consist of fuel systems, combustion systems, steam and water systems, electrical systems and control systems. Failure may occur in all power-plants systems: economizers, water walls, reheaters and superheaters. The failure of the boiler water wall tube is usually related to the tube's manufacturing method, and the equipment is exposed to the field and the entire environment after manufacture including conditions during shipment, normal operation and shutdown. ${ }^{7}$ According to the location of the failure, the water-wall tube is the second largest failure location after the superheater tubes in steam and water systems. However, in terms of the failure condition of the materials, carbon steel tubes are statistically the most common boiler tube material that causes failure. The inner and 
outer surfaces of the boiler tube were exposed to different working environments (i.e., water side and fire-facing side, respectively), which may cause microstructure degeneration to the tube. ${ }^{8-10}$ According to statistics, the damage to boiler tubes inflicts $\$ 5$ billion loss to power plants every year. ${ }^{11}$ If the surface of the tube wall surface is covered with oxides or deposits, the metal temperature could gradually go up over the years with the growth of the thickness of the cover products on the tube. ${ }^{12}$ Several investigations have been concerned with reporting failure cases in thermal power plants, failure causes range from those associated with high temperature to others caused by corrosion factors. ${ }^{13-15} \mathrm{P}$. Munda et al. ${ }^{16}$ investigated the evolution of different microstructures during the short-term overheating failure of a boiler water wall tube made of SA210 Grade C steel. They found that overheating caused degeneration of the initial ferrite-pearlite. D. N. Adnyana ${ }^{17}$ analyzed four leakage heat-exchange tubes in service for only one, results of the failure analysis showed that the leaked tubes of the heat exchanger had primarily experienced stress-corrosion cracking (SCC) in the longitudinal direction caused by the combined effects of tensile stress and corrosion. A. Kumari et al. ${ }^{18}$ investigated the typical premature failure of water wall tubes of two thermal power plant boilers with the same capacity, the same operational parameters, but with different boiler-water chemistry compositions, and the cause of corrosion was identified and the proposed strategies for their elimination were given. M. Nurbanasari et al. ${ }^{19}$ reported a failure analysis on the water-cooling distribution pipe in a 175-MW hydroelectric power plant, the results strongly evidence that the leakage occurred on the base metal due to the severe erosion-corrosion at the localized area. A. D. Camilo et al. ${ }^{20}$ have studied the causes of failure of boiler water-cooled tube wall. It was found that tensile residual stress from an inadequate stress-relief treatment prior to service and high concentration of dissolved oxygen in the feed water was the main reasons for the premature failure. E. S. Kim. ${ }^{21}$ analyzed the cause of physical explosion of boiler tube, they found that the rupture may be caused by overheating induced by insufficient water on the boiler, and it could be accelerated by the metal temperature increase. Because the boiler water-wall tube tends to suffer from failure, which can lead to power plant shutdown, this causes a certain economic loss to the power plant and brings inconvenience to the power consumers. Hence, investigating the root cause of failure is critical to avoiding the recurrence of this situation.

Failure of the boiler water-wall tube material is SA-210 Grade C, which is medium-carbon manganese steel, and is extensively used in the boiler water-wall tube of power boilers due to its excellent mechanical properties at elevated temperatures. The diameter and thickness of the tubes are $60 \mathrm{~mm}$ and $6.75 \mathrm{~mm}$, respectively. The boiler water-wall tube runs at a pressure of $11 \mathrm{MPa}$ and at a temperature of $340{ }^{\circ} \mathrm{C}$, and this information was provided when the failure occurred. The referred boilers use pulverized coal to produce steam for the continuous electricity generation. The leakage point is located on the fire-side of the main burner and close to the boiler, which belongs to a relatively high heat load area. It was reported that the boiler started service in January 2013 and failed in February 2019, but the design life of boiler tube is 20 years. After 6 years of service, leakage of the failed tubes was reported in an overhaul, which caused the power station to stop generating electricity. Several mandatory preventive maintenance practices were carried out every 6 months before failure to facilitate inspection.

In this present investigation, the causes of leakage reasons in boiler water-wall tube was studied by different microscopic and analytical techniques to identify the cause of failure. Moreover, some suggestions to prevent similar failures have been made.

\section{EXPERIMENTAL PART}

The failure analysis was performed on the leakage tube section provide by the power plant, especially the leakage and bulging section of the tube. In order to detect the surface morphology of the inner wall and other subsequent detailed analyses, the leakage tube was cut along the cross section and some microstructure/hardness samples were collected from different locations. The metallography samples were prepared using standard metallographic techniques, and the samples were etched with a $2 \%$ natal solution to display the microstructural constituents. Metallographic examinations of the leakage specimens and normal specimens were carried out with a metallographic WMJ-9950 microscope. In order to determine the main mechanism of the failure, the microstructure was analyzed by an optical and a scanning electron microscope equipped with an energy-dispersive X-ray analysis facility. The hardness near the leakage area and the normal area is determined. Average hardness data were obtained from six measurement on the microstructure samples conducted on the Vickers hardness tester (MHVS-50, China) with a $30-\mathrm{kg}$ load and a dwell time of $15 \mathrm{~s}$. The tensile tests were concluded on a UTM5305 microcomputercontrolled electronic universal testing machine. In addition, the chemical composition and microstructures of the samples were analyzed at $500 \mathrm{~mm}$ from the leakage point to verify the material of the failure tube. The material's chemical composition of the boiler water-wall tube was determined by spectral analysis, and the thickness of the tube wall was measured with a micrometer. 


\section{RESULTS AND DISCUSSION}

\subsection{Visual examination}

Visual inspection of the damaged water-wall tubes was used to check for signs of corrosion, leakage points and deformation etc., and the evidence was photographed. The position of the leakage area on the boiler water wall tube was shown in Figure 1a. An enlarged observation of the leakage area, the clear macro morphology of the leakage point was shown in Figure $\mathbf{1 b}$. The oxidation layer on the surface of the water-wall tube was observed, but blackening and abnormal thickness were not found. To detect the condition of the tube's inner surface, the tube was radially sectioned, and a macroscopic view of the cross-section is shown in Figure 2a. The leakage area presents an inverted drop shape, and the thickness of leakage point positon is thinned (the thinnest part is $2 \mathrm{~mm}$ ). Deposits attached to the inner surface of the leakage area can be observed. Diameters measured at different locations of the tube wall are shown in Table 1. The variation in dimensions at the leakage area indicates a significant bulging and deformation occurred during the tube failure and the maximum diameter of the tube wall bulge position reaches $63 \mathrm{~mm}$, which exceeds the original diameter of $60 \mathrm{~mm}$. When the deposits are viewed from the inner wall, the internal thread characteristic can be observed. The color of the inner tube wall is reddish brown and the exfoliated metal covering the inner wall of the pipe, as shown in Figure 2b.

Table 1: Dimensions at different locations of the leak tube

\begin{tabular}{|l|c|c|}
\hline \multicolumn{1}{|c|}{ Location } & $\begin{array}{c}\text { Outer } \\
\text { diameter/mm }\end{array}$ & $\begin{array}{c}\text { Wall } \\
\text { thickness/mm }\end{array}$ \\
\hline At leakage point & 63 & 2 \\
\hline Near leakage point & 61.5 & 6.6 \\
\hline Away leakage point & 60.5 & 6.8 \\
\hline Initial specifications & 60 & 6.75 \\
\hline
\end{tabular}
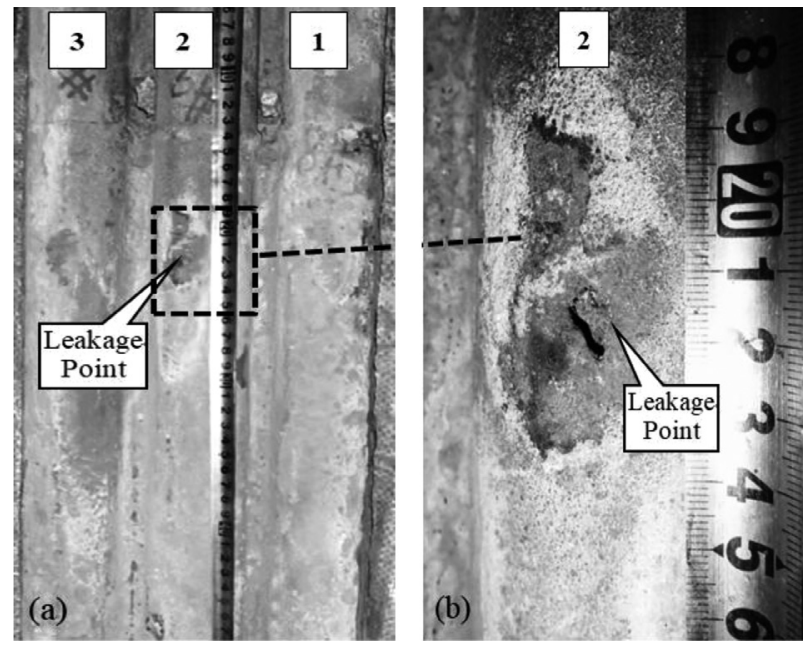

Figure 1: Photograph of failed water wall tube and the macro morphology of leakage point: a) the position of the leakage point, b) macro morphology of the leakage point

\subsection{Material chemical composition analysis}

The material chemical composition of the failed water-wall tubes was analyzed with a FOUNDERYMASTERPRO emission spectrometer with an analytical accuracy of $\pm 0.01 \mathrm{w} / \%$. The chemical composition of the tube is obtained in Table 2. The chemical composition of the tube met the designated standard specification of DL/T991-2006 22 . Therefore, compared with the standard chemical composition of steel, there is no significant difference in the chemical composition of the tube.

Table 2: Material chemical composition of the boiler water-wall tube (weight percentage, \%)

\begin{tabular}{|l|c|c|c|c|c|c|}
\hline \multicolumn{1}{|c|}{ Content } & $\mathrm{C}$ & $\mathrm{Mn}$ & $\mathrm{Si}$ & $\mathrm{P}$ & $\mathrm{S}$ & $\mathrm{Fe}$ \\
\hline $\begin{array}{l}\text { Standard } \\
\text { requirement }\end{array}$ & $\leq 0.35$ & $\begin{array}{c}0.29- \\
1.06\end{array}$ & $\geq 0.10$ & $\leq 0.035$ & $\leq 0.035$ & $\mathrm{Bal}$ \\
\hline $\begin{array}{l}\text { Measured } \\
\text { value }\end{array}$ & 0.252 & 0.75 & 0.24 & 0.016 & 0.0008 & $\mathrm{Bal}$ \\
\hline
\end{tabular}

\subsection{Mechanical properties test}

\subsubsection{Tensile properties}

In order to verify the compliance of the tensile properties, the tensile test was performed on a UTM5305 microcomputer-controlled electronic universal testing machine. The tensile tests were carried out on six
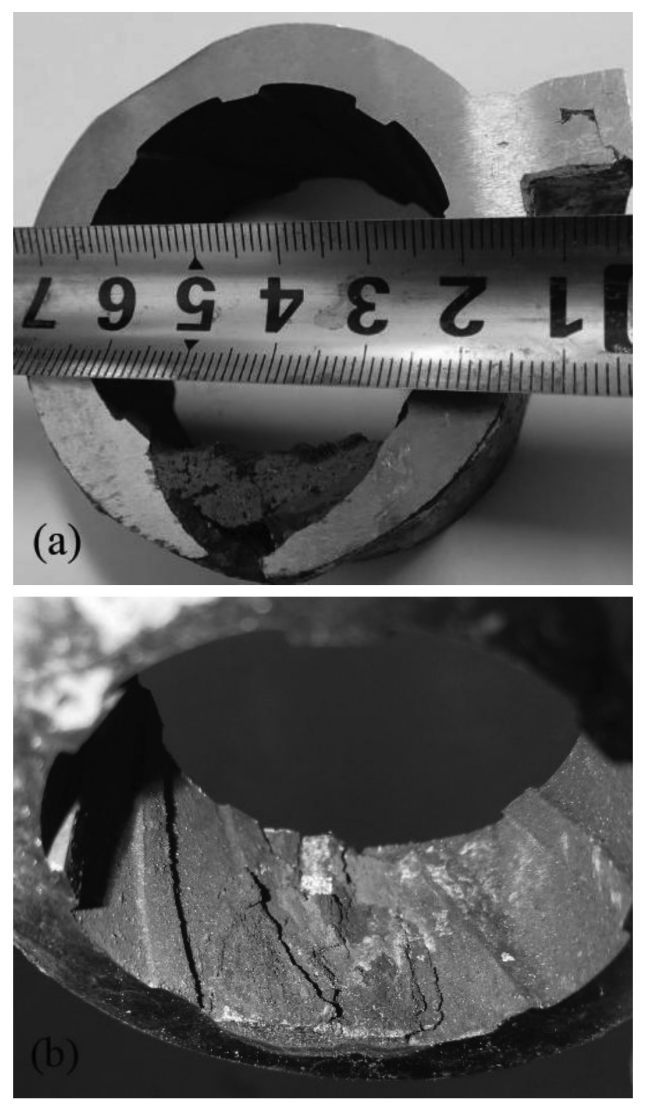

Figure 2: Close views of the tube at failed region shows: a) the morphology leakage point cross-section, b) the morphology of inner wall 
standard samples, three samples from the normal base metal and three samples from failed tubes. The tensile properties of the tube were tested with specimens extracted from the leakage tube and machined respectively according to GB/T228.1-2010 Metallic Materials-Tensile Testing-Part 1: Method of test at room temperature. ${ }^{23}$ The yield strength $\left(R_{\mathrm{p} 0.2}\right)$, tensile strength $\left(R_{\mathrm{m}}\right)$ and percentage elongation after fracture $\left(A_{50 \mathrm{~mm}}\right)$ are collated in Table 3. The tensile test results conform to the specified standard SA-210 Grade C steel. Therefore, the degradation of the tensile properties is not considered.

Table 3: Mechanical properties of the different tubes

\begin{tabular}{|l|c|c|c|}
\hline \multicolumn{1}{|c|}{ Items } & $R_{\mathrm{m}} / \mathrm{MPa}$ & $R_{\mathrm{p} 0.2} / \mathrm{MPa}$ & $\mathrm{A}_{50 \mathrm{~mm}} / \%$ \\
\hline $\begin{array}{l}\text { Standard value in GB/T228.1- } \\
2010 \text { and GB/T231.-2009 }\end{array}$ & $\geq 485$ & $\geq 275$ & $\geq 30$ \\
\hline Measured value & 532 & 334 & 36 \\
\hline
\end{tabular}

\subsubsection{Hardness measurement}

In order to check whether the hardness is qualified, the hardness measurements were carried out from the undamaged zone of the failed tube and a normal tube. The Vickers hardness was measured using a hardnesstesting machine (MHVS-50, China) with a 30-kg load and converted to the corresponding Brinell hardness values. The hardness values of each measuring point are shown in Table 4. The average hardness of the tube was 155.5 HB, which meets the standard requirements GB713-2014. ${ }^{24}$ However, the hardness close to leakage points was lower than the other undamaged areas and the normal area measured points. Due to the poor heat-transfer performance of the deposits, this causes the heat inside of the water-wall tube not be transmitted over time. Local overheating over the working temperature causes a material flow and softening of the water-wall tube.

Table 4: Micro-hardness test results (unit: HB)

\begin{tabular}{|l|c|c|c|c|c|c|}
\hline Measuring point & 1 & 2 & 3 & 4 & 5 & 6 \\
\hline Measuring values & 162 & 142 & 161 & 140 & 163 & 165 \\
\hline Average value & \multicolumn{7}{|c|}{155.5} \\
\hline Standard requirements & \multicolumn{7}{|c|}{$130-180$} \\
\hline
\end{tabular}

Note: Measured points 2 and 4 are close to a leakage point

\subsection{Metallography}

The microstructures of the failure tube and the normal tube were examined in detail, the aim to being know the microstructural constituent phases in the microstructures of the failed tube and the normal tube. The specimens were selected from different sections of the failed tube, then polished and etched with $2 \%$ Nital solution. The metallographic structure of the failed specimens near the leakage point consisted of ferrite + pearlite structure, and pearlite was distributed in a strip, as shown in Figure 3a. The metallographic structure of the normal specimens was shown in Figure $\mathbf{3 b}$, which is also a ferrite + pearlite structure. All the microstructures of the test specimens conform to the standard requirements, and these test results are consistent with the test results of the contrast samples, conforming to the designated SA-210 Grade C steel. At the cross-section of the leakage point, creep holes were observed on the inner wall, as shown in Figures 3c and 3d. The pearlite structure at the leakage point was seriously spheroidized due to overheating, and the grains were elongated due to plastic deformation (Figure 3e). Microstructure observations revealed that the grains were elongated, which indicates that plastic deformation occurs at high temperature. Overheating caused a degeneration of the initial ferrite-pearlite microstructure. Spheroidization and coalescence of the carbides occurred in the matrix of the boiler tube near the leakage-point region. At the edge
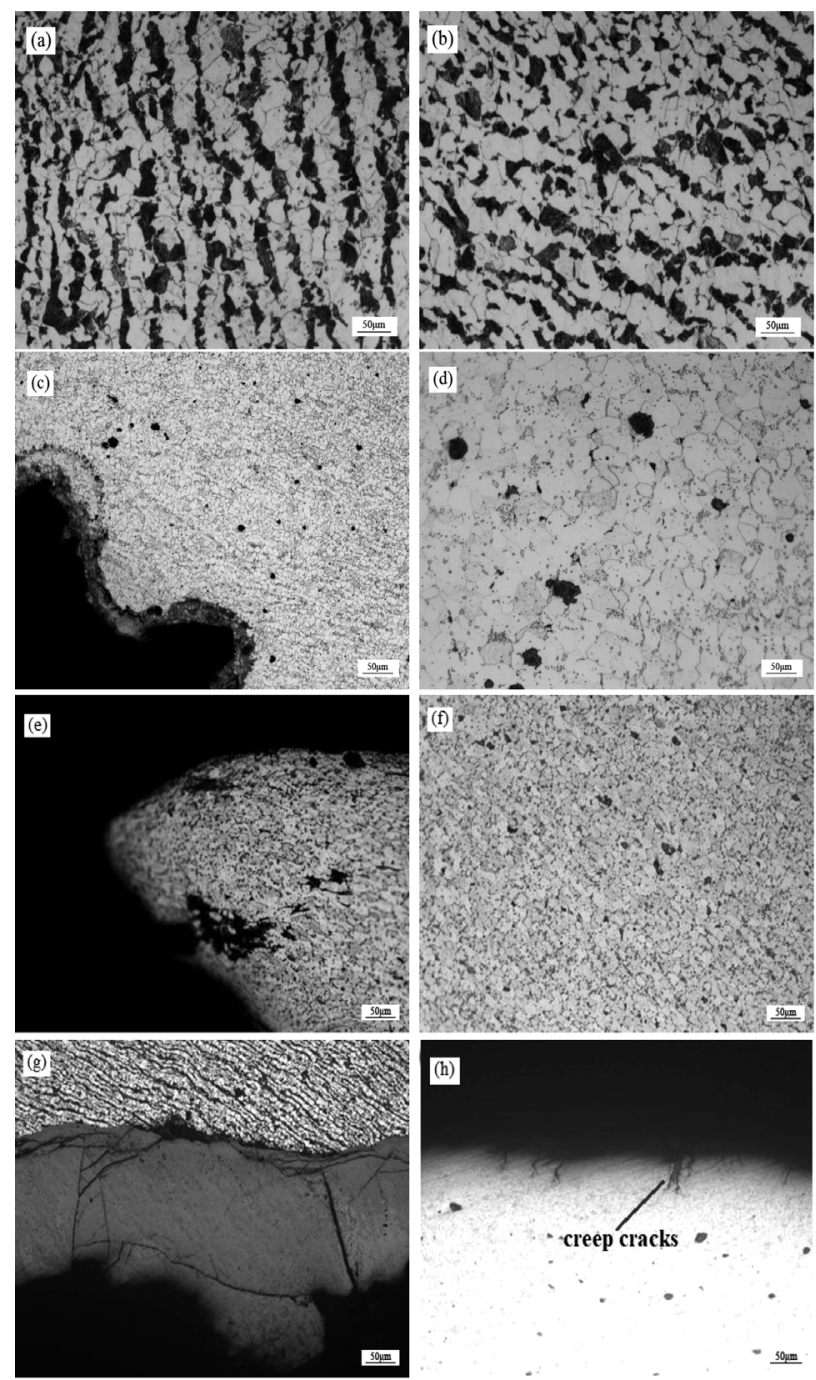

Figure 3: Microstructure obtained from different regions of boiler water-wall tubes specimens: a) microstructure near leakage point, b) microstructure of normal specimens, c) and d) creep holes, e) pearlite structure spheroidized and grains were elongated, f) precipitated carbides, g) deposits were attached to tube inner wall, and presented in a layered structure, h) creep cracks in the outer wall near the leakage point 

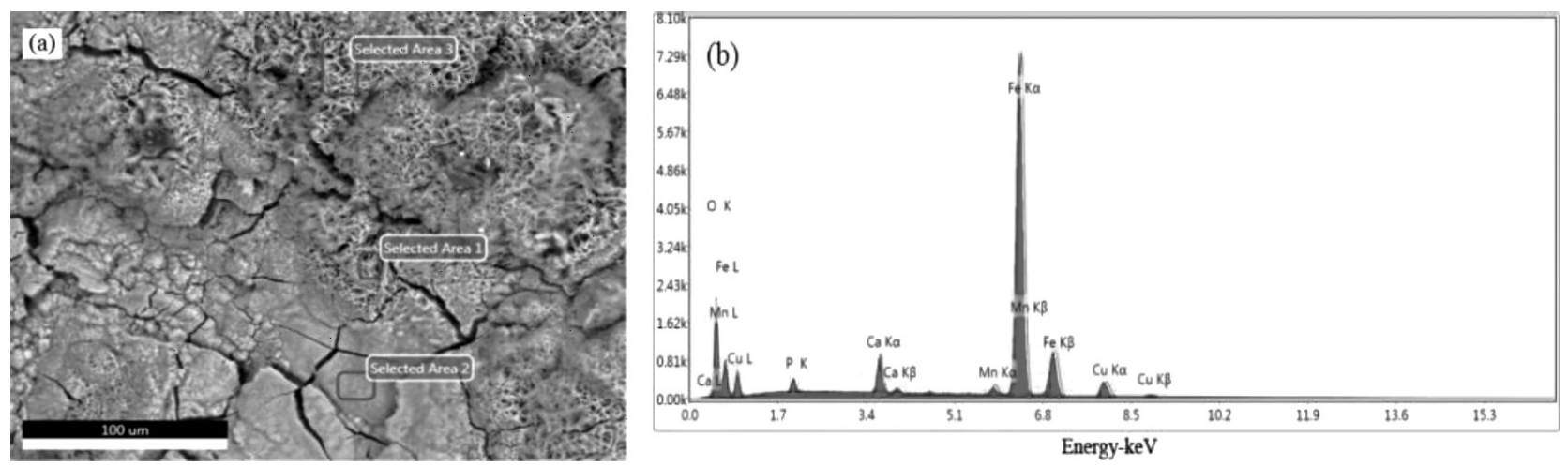

Figure 4: SEM morphology and EDS test results: a) SEM morphology of deposits covering area in the tube inner wall, b) energy-dispersive spectroscopy analysis of deposits

of the leakage point, a severely spheroidized pearlite microstructure and a large number of precipitated carbides were observed, shown in Figure 3f. According to DL/T884-2004,25 the microstructure aging level near the leakage point was graded at 4.5 . These microstructural changes were due to the atomic migration at high temperatures. When the temperature is above $280{ }^{\circ} \mathrm{C}$ and lower than the eutectoid temperature, the cementite in the pearlite spheroidized. Changing the shape of the layer of cementite to a sphere can reduce its internal energy. In Figure 3g the deposits were attached to the tube inner wall of the leakage point. Figure $\mathbf{3 h}$ shows that the deposits mainly presented in a layered structure, and the thickness of the tube thinned at the deposits' covered zone. Due to the deposits formed on the inner wall, which caused the local heat-transfer performance of the water-wall tube to decrease and the tube's overall performance deteriorated, creep cracks formed in the outer wall near the leakage point, as shown in Figure 3j.

\subsection{Detection of components and phase structure of inner wall deposits}

The chemical composition of the deposits on the inner wall is detected using energy-dispersive spectroscopy (EDS). The deposits sample was selected from the tube to determine the chemical composition. Figure 4a shows the inner wall morphology at the leakage position, with deposits present as the spallation state. The EDS test results are presented in Figure $\mathbf{4 b}$ and the deposits mainly contained $\mathrm{Fe}$ and $\mathrm{O}$. Furthermore, the deposits also contained a few $\mathrm{Ca}, \mathrm{S}$, and Mn elements, as shown in Table 5.

Furthermore, the component analysis of the sediments separated and accumulated on the inner surface of the pipe near the leakage point was carried out with $\mathrm{X}$-ray fluorescence spectrometry and the test results were listed in Table 6. According to the test results, it was found that the deposits consist of the compound $\left(\mathrm{CaSO}_{4}\right)$ and the corrosion products $\left(\mathrm{Fe}_{2} \mathrm{O}_{3}\right)$, which indicate that the failed tube suffered a corrosion attack.
An X-ray test result is consistent with the results of the energy spectrum test.

Table 5: Energy spectrum test results of inter wall deposits (weight percentage, \%)

\begin{tabular}{|c|c|c|c|c|c|}
\hline Element & $\mathrm{Fe}$ & $\mathrm{O}$ & $\mathrm{Ca}$ & $\mathrm{Mn}$ & $\mathrm{S}$ \\
\hline Measured values & 66.74 & 28.66 & 2.08 & 0.78 & 1.74 \\
\hline
\end{tabular}

Table 6: X-ray test results of inter wall deposits on fire-facing side $(\%)$

\begin{tabular}{|c|c|c|c|c|c|}
\hline Element & $\mathrm{Fe}_{2} \mathrm{O}_{3}$ & $\mathrm{CaO}$ & $\mathrm{CaSO}_{4}$ & $\mathrm{CuO}$ & $\mathrm{MnO}_{2}$ \\
\hline Measured values & 88.9 & 1.60 & 7.39 & 0.45 & 1.66 \\
\hline
\end{tabular}

\section{CONCLUSIONS}

In this paper the leakage reasons analysis of a boiler water-wall tube was performed. Based on the above analysis and discussions, the following conclusions can be drawn:

a) The deposits formed on the inner wall caused the local heat-transfer performance to decrease, which caused local overheating and softening.

b) The bugling brings local softening, which formed local thinning.

Above all, the tube leakage at the location where the deposits covered (at the bulge position).

\section{RECOMMENDATIONS}

Future actions to prevent failures are as follows:

a) Boiler sewage and water quality test should be carried out regularly to prevent deposits from forming on the inner tube wall. In addition, clean up the deposits formed in the inner tube wall in time to avoid local overheating of the tube.

b) Preventing the boiler tube from exceeding the working temperature and working pressure, and regular cleaning with a boiler tube wall thickness inspection. 


\section{Acknowledgement}

This work was partially supported by doctoral fund of Southwest University of Science and Technology (Grant No.13zx7153) and opening project of Key Laboratory of Testing Technology for Manufacturing Process, Ministry of Education, Southwest University of Science and Technology (Granted No. 13zxzk04), PR China.

\section{REFERENCES}

${ }^{1}$ A. Ogundipe, O. Akinyemi, Electricity consumption and economic development in Nigeria, Soc. Sci. Electron. Publication., 6 (2016) 1, doi:10.2139/ssrn.2472463

${ }^{2}$ E. K. Ogunleye, Political Economy of Nigerian Power Sector Reform, UNU-WIDER, Helsinki, 2016

${ }^{3}$ S. W. Liu, W. Z. Wang, C. J. Liu, Failure analysis of the boiler water-wall tube, Eng. Fail. Anal., 9 (2010), 35-39, doi:10.1016/ j.csefa.2017.06.002

${ }^{4}$ S. K. Dhua, Metallurgical investigation of failed boiler water-wall tubes received from a thermal power station, Eng. Fail. Anal., 17 (2010), 1572-1579, doi:10.1016/j.engfailanal.2010.06.004

${ }^{5}$ J. Ahmad, J. Purbolaksono, Hydrogen damage in a rear riser water wall tube of a power plant, Eng. Fail. Anal., 17 (2010), 1239-1245, doi:10.1016/j.engfailanal.2010.01.005

${ }^{6}$ J. Ahmad, J. Purbolaksono, L. C. Beng, A. Z. Rashid, A. Khinani, A A. Ali, Failure investigation on rear water wall tube of boiler, Eng. Fail. Anal., 16 (2009), 2325-2332, doi:10.1016/j.engfailanal.2009. 03.012

${ }^{7}$ ASM Handbook, Failure Analysis and Prevention, vol. 11, 6th edn. (ASM International, Materials Park, 1998), 628-642

${ }^{8}$ D. R. H. Jones, Creep failures of overheated boiler, superheater and reformer tubes, Eng. Fail. Anal., 11 (2004), 873-893, doi:10.1016/ j.engfailanal.2004.03.001

${ }^{9}$ K. Ranjbar, Failure analysis of boiler cold and hot reheater tubes, Eng. Fail. Anal., 14 (2007), 620-625, doi:10.1016/j.engfailanal. 2006.03.007

${ }^{10}$ M. Nurbanasari, H. Abdurrachim, M. M. Prihadi, Failure analysis of secondary superheater tube in a 600-MW coal power plant, J. Fail. Anal. Prev., 19 (2019), 453-460, doi:10.1007/s11668-019-00619-9

${ }^{11}$ J. G. Chacón-Nava, A. Martínez-Villafañe, F. M. Almeraya-Calderón, F. H. Stott, J. G. González-Rodríguez, The erosion-corrosion performance of SA213-T22 steel in low-velocity conditions, J. Mater. Eng. Perform., 10 (2001), 699-704, doi:10.1361/ 105994901770344575
${ }^{12}$ H. S. Babak, F. N. Hossein, N. S. Masoud, A. Pooria, N. Farzad, Failure analysis of a superheater tube ruptured in a power plant boiler: Main causes and preventive strategies, Eng. Fail. Anal., 98 (2019), 131-140, doi:10.1016/j.engfailanal.2019.01.016

${ }^{13}$ A. Saad. Abou-Elazm, I. EI. Mahallawi, R. Abdel-Karim, R. Rashad, Failure investigation of secondary super-heater tubes in a power boiler, Eng. Fail. Anal., 16(2009), 433-438, doi:10.1016/j.engfailanal.2008.06.024

${ }^{14}$ P. M. Singh, J. Mahmood, Stress assisted corrosion of waterwall tubes in recovery boiler tubes: failure analysis, J. Fail. Anal. Prev., 7 (2007), 361-70, doi:10.1007/s11668-007-9063-z

${ }^{15}$ J. J. Perdomo, T. D. Spry, An overheat boiler tube failure, J. Fail. Anal. Prev., 5 (2005), 25-28, doi:10.1361/15477020522997

${ }^{16}$ P. Munda, Md. M. Husain, V. Rajinikanth, Evolution of microstructure during short-term overheating failure of a boiler water wall tube made of carbon steel, J. Fail. Anal. Prev., 18 (2018), 199-211, doi:10.1007/s11668-018-0394-8

${ }^{17}$ D. N. Adnyana, Failure analysis of stainless steel heat exchanger tubes in a petrochemical plant, J. Fail. Anal. Prev., 18 (2018), 413-422, doi:10.1007/s11668-018-0422-8

${ }^{18}$ A. Kumari, S. K. Das, P. K. Srivastava, Feed water chemistry-related corrosion failures in subcritical $250 \mathrm{MW}$ coal-fired boiler, J. Fail. Anal. Prev., 16 (2016), 703-711, doi:10.1007/s11668-016-0150-x

${ }^{19}$ M. Nurbanasari, T. S. Purwanto. R. S. Pillang, T. Kristysdi, E. Saefudin, Y. Irwan, Leakage on water cooling distribution pipe in a hydroelectric power plant, J. Fail. Anal. Prev., 19 (2019), 412-417, doi:10.1007/s11668-019-00610-4

${ }^{20}$ A. D. Camilo, E. Edgar, C. M. Juan, Failure analysis of the wall tubes of a water-tube boiler, Eng. Fail. Anal., 79 (2017), 704-713, doi:10.1016/j.engfailanal.2017.05.032

${ }^{21}$ E. S. Kim, Fracture analysis of tube boiler for physical explosion accident. Fore. Sci. Inter., 278 (2017), e1-e7, doi:10.1016/j.forsciint. 2017.07.036

${ }^{22}$ Standards for the Electric Power Industry of People's Republic of China. DL/T991-2006 Spectral analysis guideline of metal for electrical power equipment

${ }^{23}$ The standard of People's Republic of China. GB/T228.1-2010 Metallic materials-Tensile testing-Part 1: Method of test at room temperature

${ }^{24}$ The standard of People's Republic of China.GB713-2014 Steel plates for boilers and pressure vessels

${ }^{25}$ Standards for the Electric Power Industry of People's Republic of China, DL/T884-2004, Power plant metallography inspection and assessment guideline 